\title{
CONECTADOS NA INTERNET, INSPIRADOS NA ESCOLA: Ações pedagógicas com a Língua Portuguesa no IFRJ
}

Robson Fonseca Simões ${ }^{(*)}$

E para estas duas vidas, um léxico só não é suficiente. Guimarães Rosa

\section{UNIVERSO VIRTUAL À VISTA: CONSIDERAÇÕES INICIAIS}

A inspiração poética de Guimarães Rosa, como num vaticínio linguístico, abre portas para podermos ampliar as discussões sobre ações pedagógicas nas veredas da Língua Portuguesa, considerando os sujeitos do Ensino Médio/Técnico, os desafios da formação humana integral e as ações pedagógicas diferenciadas nos horizontes do aprender, do saber e do emancipar-se. Sem a pretensão de esgotarmos o debate sobre práticas possíveis com a língua materna, a poesia procura inspirar educadores a (re)desenharem as suas ações pedagógicas no esforço em possibilitar uma educação de qualidade social, que contribua decisivamente para a construção de uma sociedade mais justa e mais fraterna. Mas quais são os desafios dos professores de Língua Portuguesa na última etapa da Educação Básica?

Nós e nossos estudantes estamos constantemente nos defrontando com a inevitável mediação das linguagens. A prática de um esporte, a escrita de um e-mail, a ação de fotografar e expor essa fotografia são formas de produção de sentidos que se dão como linguagens. Além disso, quando as práticas de linguagem adentram o espaço escolar, elas trazem consigo as identidades de diferentes grupos sociais e, ao serem trabalhadas como conhecimento, saber e reflexão, elas exercem um importante papel no processo de constituição do sujeito e, portanto, do estudante como sujeito em constituição.

A minha experiência como educador na área de códigos e linguagens fez perceber que cada vez mais os estudantes vinham trazendo para a escrita na escola, “ecos” de uma linguagem típica da internet, cheia de signos, símbolos e abreviaturas; no esforço em se poder refletir sobre essas questões, no ano de 2005, fiz parte de uma banca examinadora que elaborou e corrigiu a prova de seleção ao Instituto Federal de Educação, Ciência e Tecnologia do Rio de Janeiro ${ }^{1}$ cujo tema foi

\footnotetext{
${ }^{(*)}$ Doutor em Educação; Docente da Universidade Federal de Rondônia, no Departamento de Ciências da Educação, Campus Porto Velho (UNIR). E-mail: fonsim2000@hotmail.com.
}

${ }^{I}$ Instituição pública federal de ensino Técnico-Médio no estado do Rio de Janeiro. 
internet, a fim de suscitar nos candidatos, possíveis reflexões sobre o sentido desse aparato tecnológico nas escritas do mundo contemporâneo. ${ }^{2}$

O universo contemporâneo entra em cena com recursos tecnológicos tão poderosos que despertam cada vez mais novas experiências nos mais diversos segmentos da sociedade contemporânea, sobretudo o da juventude. Entendo que o educador do mundo contemporâneo deva estar sintonizado com a pedagogia dos tempos tecnológicos que exige a leitura das diferentes linguagens que estão postas no mundo, o que pode nos remeter à epígrafe deste estudo. Charlot (2000) acena que a relação com o saber é uma aliança com sistemas simbólicos, notadamente, com a linguagem; nessa acepção, os recursos da comunicação vêm implementando um novo diálogo com o processo ensino-aprendizagem, permitindo, assim, que a Educação dialogue com um tempo cada vez mais digital.

Habituados com o universo virtual, cada vez mais os sujeitos vinham trazendo para a escrita na escola "ecos" de uma linguagem típica da internet, cheia de signos, símbolos, abreviaturas etc. Essa transposição, muitas vezes me causava um estranhamento no universo escolar, calcado numa perspectiva de trabalho com a língua a partir da sua normatividade. Será que a língua normativa da escola é a única no mundo?

Minha atenção para o chamado "internetês" foi despertada junto à prática da disciplina Língua Portuguesa no Ensino Médio/Técnico do Instituto Federal do Rio de Janeiro, campus Rio de Janeiro. Percebia a utilização constante dessa nova manifestação linguística nas composições e demais atividades em sala de aula. Esse discurso escrito é formado por uma série de elementos ora do mundo virtual, ora da gramática normativa, instituindo um mosaico linguístico. Nesse palco de vozes inconclusas, percebia que os sujeitos articulavam os domínios das linguagens imbuídos de subjetividade.

Entendo que pensar o universo virtual é olharmos os instrumentos, as ferramentas utilizadas pelos estudantes ora na escola, ora fora dela, na lan house, ora na sua residência. Assim, os meus olhos percebiam a invasão do cotidiano pela internet com os sites especializados, blogs, flogs, orkut e softwares educativos, obrigando-me a repensar a relação histórica entre oralidade, textos, escrita e imagem.

\footnotetext{
${ }^{2}$ A banca se deparou com os seguintes trechos: “[...]A internet ajuda mas se vc não entender, ela prejudica"; “ [...]elas naum param pra entender vc"; "[...]ele faz atraveis das teclas do computador e vc neim percebe"; "[...]as máquinas teem grandes utilidades pra nois"; "[...] mas é tb importante para nois a informação"; "[...] não imaginei a blz desse aparelho pra agilizar os cálculos".
} 
As práticas de linguagem são atos sociais que, fazendo uso de diferentes discursos, além de significarem e comunicarem, demarcam (KRISTEVA, 1988). Portanto, se apresentam como lugar de múltiplas contradições: arbitrariedade e flexibilidade (LYONS, 1987); significantes antigos e significados novos (FIORIN, 2003); tensão entre paráfrase e polissemia (ORLANDI, 1987).

Para Bakhtin (1992), a língua não é algo imóvel, morto ou petrificado da vida social, mas move-se continuamente, de modo que seu desenvolvimento segue a vida social. Por sua vez, Freitas (2005, p. 99) sugere: "Nas vicissitudes das palavras encontram-se as vicissitudes da sociedade dos seus usuários".

Enquanto aceitava o desafio de adentrar no universo virtual em que os sujeitos se sentiam tão à vontade, desafiava cada estudante a criar produções escritas em que precisavam se expressar usando o reino das figuras de estilo em seus enunciados escritos. Curiosamente, a riqueza dos textos e o domínio da norma culta eram enfrentados com a mesma propriedade com que faziam charges, colagens, desenhos etc.

É interessante pensar uma relação com a linguagem; os propósitos comunicativos são a base para determinar os gêneros, ou seja, os gêneros se identificam à base do uso e da necessidade comunicativa. Mas o que isso significa? Podemos dialogar com Bakhtin (1992, p. 86) quando o mesmo insistia no caráter comunicativo dos gêneros: "Os gêneros do discurso organizam nossa linguagem da mesma maneira que as formas gramaticais”. A gramática organiza as sentenças, contudo a competência linguística dos falantes deve ser considerada; Bakhtin (p.189) ratifica o caráter coletivo e social dos gêneros: "cada época e cada grupo social tem o seu repertório de formas de discurso na comunicação socioideológica".

Os propósitos comunicativos determinam os gêneros e estes dão forma aos textos; as intenções e as motivações daquele que escreve tomam forma linguística nos discursos. Compreendo que são os acontecimentos sociais que dão vida aos propósitos da comunicação, e estes, ocorrem em determinadas situações verificadas no cotidiano e se realizam através das marcas linguísticas que nos revelam a idiossincrasia, isto é, uma maneira do autor enxergar o mundo. Logo, podemos pensar que texto é como um conjunto de enunciados linguísticos, organizados seletivamente em função do gênero a que pertence.

A atividade proposta consistia em apresentar a mesma temática da prova que haviam feito para a admissão ao curso, a saber, a internet, usando as figuras de linguagem que pudessem auxiliálos a enveredarem rumo à leveza nas ideias dos seus textos. Essa atividade, de certo modo, 
desafiava cada estudante do primeiro ano do curso Médio/Técnico de Biotecnologia do IFRJ a um uso mais amplo da linguagem para aquela ocasião.

\section{MAS O QUE É ESTILÍSTICA? NAS VEREDAS DAS FIGURAS DE LINGUAGEM}

Ao refletirmos sobre a questão do estilo, na linguagem, é interessante que nos aproximemos da Estilística, para compreendermos melhor algumas considerações sobre os recursos da língua, como Elia (1978, p. 76) sugere: é "o máximo de efeito expressivo que se consegue obter dentro das possibilidades da língua".

Assim, definida como a disciplina linguística que estuda os recursos afetivo-expressivos da língua, a estilística é uma ciência recente, fundada no início do século XX pelo suíço Charles Bally e o alemão Karl Vossler, mas com um saber muito antigo, que remonta à tradicional retórica dos gregos.

Tendo em comum o estudo da expressividade, distinguem-se, contudo, por seus objetivos: a retórica era uma doutrina com finalidade pragmático-prescritiva, enquanto a estilística, como ciência, apresenta um caráter mais descritivo-interpretativo, sem considerações de natureza normativa.

Há quem veja os estudos estilísticos antes como um procedimento metodológico do que propriamente uma ciência. De acordo com essa visão, a estilística seria considerada um subdomínio das ciências da linguagem, fundamentando-se em teorias linguísticas e literárias de diversas tendências, como o idealismo, o estruturalismo, o gerativismo, a semiótica etc.

Dividida por Guiraud (1970) em estilística da língua ou da expressão e estilística genética ou do autor, em que se dá ênfase à criação expressiva individual, ela trabalha com algumas categorias básicas, como funções da linguagem, estilo, desvio e escolha. Vale dizer que estilo é o uso individual dos recursos expressivos da língua; assim, trata-se de um conceito intimamente relacionado com as noções de desvio e escolha, ou seja, a tensão entre o autor criador e as normas gramaticais.

O efeito estilístico resulta não raro da singularidade, do desvio em relação ao padrão normativo e da escolha diante das virtualidades oferecidas pelo sistema. Por exemplo, Machado de Assis (1998) optou pelo desvio gramatical, para poder reproduzir, com fidelidade, a fala do escravo Prudêncio: "É um vadio e um bêbado muito grande. Ainda hoje deixei ele (e não deixei-o ou o deixei ) na quitanda, enquanto eu ia lá embaixo na (e não à) cidade”. 
O poeta Carlos Drummond de Andrade (2004), para enfatizar a importância do deus Kom Unik Assão, não hesitou em transgredir a norma gramatical a respeito da formação do plural: "Eisme prostrado a vossos peses / Que sendo tantos, todo plural é pouco". É interessante lembrarmos, contudo, que entendemos estilístico o desvio que tem finalidade expressiva.

A representação é a linguagem referencial e denotativa, operando linearmente no eixo sintagmático. A expressão é a exteriorização psíquica de nossos anseios e sentimentos, e o apelo é o meio pelo qual exercemos influência sobre nossos interlocutores ou leitores, no caso da língua literária. Essas duas funções podem ter caráter conotativo e operar simbolicamente no eixo paradigmático. Por exemplo, uma definição do tempo de natureza puramente representativa diria: “O tempo é a sucessão das horas e dos dias e pode ser aproveitado de muitas maneiras”. Já um exemplo em que sobressaem a expressão e o apelo pode ser encontrado na elaborada e genial definição e Machadiana: “O tempo é um tecido invisível em que se pode bordar tudo".

A função de apelo adquire relevância no discurso publicitário, em frases como: "Inglês é cultura. Cultura Inglesa". Ou esta outra, exaltando a solidez de uma seguradora: "Sul América: o nosso negócio é seguro".

Quanto às relações entre a estilística e a gramática, entendemos que as duas disciplinas não são excludentes; ao contrário, são complementares, como adverte Bechara (2001, p. 88): “Ambas se completam no estudo dos processos do material de que o gênero humano se utiliza na exteriorização das ideais e sentimentos ou do conteúdo do pensamento designativo". Podemos lembrar que muitas das aparentes irregularidades registradas pela gramática têm sua origem em motivações de natureza estilística, sobretudo no campo da sintaxe. O método de análise estilística segue inclusive as divisões clássicas da gramática, daí a tripartição em estilística fônica, léxica e sintática.

Há também a Estilística fônica que estuda os recursos expressivos presentes no nível fônico da língua. Na prosódia, por exemplo, os acentos de altura e intensidade podem apresentar valor afetivo. Assim, a evocação sonora sugerida pelos fonemas também pode ser explorada estilisticamente nas aulas de português. Veja-se, por exemplo, a poética de Bandeira (1999):

Sino de Belém, pelos que inda vêm!

Sino de Belém bate bem-bem-bem.

Sino da paixão, pelos que lá vão!

Sino da paixão bate bão-bão-bão

(BANDEIRA, 1999, p. 88).

O poema deixa entrever que a aliteração do /b/ e a reiteração de vocábulos labiais podem evocar fonicamente o tanger dos sinos. A onomatopeia bem-bem-bem sugere o som metálico e 
alegre "pelos que inda vêm" (os batizados); bão-bão-bão, o dobre de finados "pelos que lá vão" (os mortos).

Através do estudo da estilística fônica, pode o educador despertar em seus estudantes o gosto pelo bom uso dos recursos sonoros da língua, evitando as silabadas e cacofonias nas redações escolares. Pode também chamar a atenção do estudante para o emprego expressivo das onomatopeias, aliterações, e assonâncias.

O estudo da estilística léxica permite ensinar o valor afetivo-expressivo das diversas classes de palavras. Sirvam de exemplos: a passagem de substantivos abstratos a concretos através da pluralização ("Tive uns amores, perdi-os", Manuel Bandeira); a conversão dos substantivos concretos em abstratos por meio da metaforização ("Não quero a rosa que me dás, quero a rosa que tu és."); a substantivação de adjetivos ("A curiosidade agitada dos alunos" = alunos curiosos e agitados).

A sintaxe, por atuar na frase e por sua versatilidade, oferece variada gama de recursos expressivos, por isso, talvez seja o campo de estudo estilístico mais fértil de nossa língua. $\mathrm{O}$ emprego das diversas classes de palavras aí deve ser incluído, com proveito para o educador e o educando. Quanto às partes tradicionais em que se divide o plano sintático, vejamos a seguir algumas sugestões de estudo.

Na sintaxe de colocação, cabe ressaltar a posição do adjetivo como marcador semânticoestilístico (pobre homem = homem infeliz; homem pobre = carente de recursos), a permutabilidade substantivo/adjetivo (autor defunto/defunto autor), os casos de hipálage (“As criadas remendavam meias sonolentas" por "As criadas sonolentas remendavam meias"), o deslocamento e a elipse de termos, o anacoluto, a colocação pronominal, todos constituem recursos expressivos, quando produzidos com motivação estilística.

Portanto, entendemos que o campo da concordância é rico em recursos expressivos. Aprecie-se este passo de Vieira (1998, p. 56): "Muito trabalhou o diabo e seus ministros para que eu não viesse a Portugal". Deixando no singular o verbo anteposto ao sujeito composto, talvez o grande orador tivesse a intenção de carregar sobre o diabo, pondo-o em primeiro plano e relegando a condição secundária os ajudantes do coisa ruim. Mesmo com o verbo posposto, em sua posição usual, é possível deixá-lo invariável quando a intenção estilística é valorizar cada núcleo do sujeito composto: "Mas nem a lisonja, nem a razão, nem o exemplo, nem a esperança bastava a lhe moderar as ânsias". 


\section{EXPERIÊNCIAS COM A LÍNGUA MATERNA NA SALA DE AULA}

A língua, espelho da cultura, reflete essa busca desenfreada pela novidade, evoluindo incansavelmente, introduzindo novos termos linguísticos, que ora são desconhecidos, para posteriormente, poderem fazer parte do novo léxico na língua portuguesa. Mas por que se formam novas palavras?

A resposta para essa pergunta está relacionada a três fatores: as exigências do sistema linguístico, a influência do falante e ao papel das funções semânticas. Assim, podemos refletir sobre as três funções na formação de palavras (Basílio, 2004): função de mudança categorial (por exigência do sistema linguístico); função expressiva de avaliação (por influência do falante) e função de rotulação (relacionada com o aspecto semântico).

Quando se formam novas palavras? Novos itens lexicais são formados a todo momento na Língua Portuguesa, nas suas mais diversas modalidades: coloquial, culta, literária, técnica, científica, de propaganda etc. Esse movimento da linguagem propicia um diálogo entre locutores e seus interlocutores, anunciando uma nova proposta de comunicação a cada cenário que se faz presente no mundo. Nessa acepção, retomo Bakhtin (1992) para enfatizar a relação dos sujeitos com a língua, relação esta que determina a enunciação e marca a presença da subjetividade no discurso.

Tentar traduzir o "internetês" trazido pelos estudantes e convidá-los a que me apresentassem uma lan house, foram meus primeiros sinais de abertura ao estranhamento; uma proposta metodológica que precisou de uma ajuda de um dicionário e dos próprios sujeitos da turma. Daí nasceu o desejo de conhecer as produções escritas dos estudantes na sua vida social, tanto para melhor conhecê-los, quanto para poder compreender as transformações da linguagem, vista como produção humana.

Fui convidado a participar do Orkut da turma. Trata-se de uma comunidade virtual que preza a amizade, mensagens de bom humor, sugestões de restaurantes e parques, avisos de provas agendadas, comentários do período de greve. Esses estudantes/membros também pertencem a outras comunidades: "O Pedro fala muito"; "Bean, impossível não rir"; "Luiza, impossível não gostar"; "Eu amo a Erikita"; "Gabriel, sem comparação"; "Camila, tu eh demais".

Para se apresentarem em suas páginas, escolhem a sua melhor foto e registram nos seus perfis um pouco do que gostariam de falar sobre eles mesmos. Entre fotos e palavras, sua história e seus desejos ganham forma. Uma estudante, por exemplo, escreve que se pudesse prever o futuro, gostaria de saber qual é o destino daqueles que fazem acreditar que são confiáveis, amigos e sinceros, mas acabam decepcionando; ela gostaria de entender o que está mudando nela e o motivo 
desta mudança. A estudante registra as suas paixões na vida, seu livro preferido, sua melhor música e cinema. Muitas vezes, é nesse espaço virtual que questões invisíveis à família e à escola ganham visibilidade.

Ia conhecendo os seus territórios sociais, aproximava-me das suas redes de sociabilidade; e ao mesmo tempo, na sala de aula, procurava convidá-los a expressarem os seus enunciados cujo tema também era a internet, num exercício de escrita com as figuras de estilo.

\section{ESCRITAS DOS SUJEITOS: A ESTILÍSTICA EM FOCO}

No esforço em poder analisar algumas escritas trabalhadas na sala de aula com os sujeitos do primeiro ano no ensino Médio/Técnico do curso de Biotecnologia do IFRJ, verificamos a seguir alguns trechos dos enunciados que trazem à tona a temática da internet no mundo contemporâneo.

É preciso, sobretudo, maturidade para saber lidar com as ferramentas do futuro. Saber selecionar o que você quer e não cair em enroscada. Afinal, mesmo com todas essas novidades muito presentes em nosso cotidiano, devemos preservar os nossos velhos e bons valores. ${ }^{3}$

De autoria da estudante Nara, ${ }^{4}$ a sua escrita ratifica a utilização da figura de estilo metáfora num esforço em poder justificar a utilização da internet nos dias de hoje, o que possibilita criar um tom de subjetividade e estilo. Não é difícil observarmos nas linhas a seguir outro exemplo na utilização desse recurso linguístico.

São realmente preocupantes os fatos relatados, por isso é necessário que cada cidadão aprendamos a controlar a vontade de sempre apelar para o que seja mais prático, pois nem sempre o que é fácil, é o melhor. ${ }^{5}$

Ao lermos as linhas acima, podemos observar a preocupação do autor em tratar a silepse, concordância que se faz com o termo que não está expresso no texto, quando utiliza "cada cidadão aprendamos", o estudante provocou um efeito de sentido na sua linguagem, incluindo-se no rol dos cidadãos que controlam a vontade de navegar na internet. $\mathrm{O}$ outro trecho a seguir ilustra outro exercício de escrita com a figura de estilo.

A internet é uma moeda: tem duas faces. Através dela estamos conectados a um mundo de informações que nos ajuda em nosso dia-a-dia. Contudo, ela pode nos tornar seu escravo e assim, nos viciar 6 .

\footnotetext{
${ }^{3}$ Trecho da escrita produzida pela aluna Nara na aula de Língua Portuguesa com os sujeitos do primeiro ano do Ensino Médio/Técnico.

${ }^{4}$ Vale destacar que por opção metodológica, os nomes dos estudantes são fictícios.

${ }^{5}$ Trecho da escrita produzida pelo aluno Pedro na aula de Língua Portuguesa com os sujeitos do primeiro ano do Ensino Médio/Técnico.
} 
O enunciado escolhido pela estudante também traz à baila a utilização da internet, elaborado com um estilo metafórico, anunciando as possíveis contradições na utilização do universo virtual. Assim, percebe-se o esforço de cada estudante em poder exercitar a sua leveza na escrita, atribuindo novos sentidos, destacando as suas experiências com a língua materna, fazendo andar o carrossel das transformações e das experiências linguísticas.

\section{POR AÇÕES PEDAGógICAS DIFERENCIADAS: CONSIDERAÇÕES FINAIS}

Vale refletir que podemos entender que a presença da Estilística nas composições e nos textos é da maior relevância. Estimula e desperta a sensibilidade linguística do educando, provocando novos sentidos, despertando novas construções de ideias nos mais diversos textos na sala de aula e fora dela, além de motivar e tornar menos árido o estudo da matéria gramatical. É interessante lembrar que muitas das aparentes irregularidades da língua têm sua origem em motivações de natureza estilística. Desse modo, cabe enfatizar que o estudo da Estilística e o da Gramática estão presentes na sala de aula, para empregarmos a nossa língua, através dos modos de falar e escrever, estimulando uma estética linguística que possa combinar com os nossos cenários sociais.

Muitas discussões, no campo linguístico, vêm se travando, mobilizando profissionais e pesquisadores da linguagem com a chegada da internet na vida e na escola. As inovações tecnológicas geraram novos meios de comunicação desmistificando a linguagem. Longe de desvalorizar o discurso escrito, os computadores incrementaram métodos e práticas tecnológicas que intensificaram novas maneiras de se comunicar. Talvez, a era da informática veio tornar ainda mais importante que anteriormente a capacidade de ler e escrever, entendendo-se por ler, decifrar, entender, analisar, interpretar textos, e, por escrever, produzir textos de diferentes gêneros para a comunicação em diferentes esferas de atividade. Assim, entendemos que as ferramentas tecnológicas, quem sabe, tenham aperfeiçoado a arte da leitura e escrita.

Ler e escrever constituem, pois, um ponto importante de atuação a que pode atingir um ser humano em uma sociedade organizada. Assim, o ato de leitura e escrita se tornou uma grande força dos homens que buscam a solidariedade, compreensão, tolerância e responsabilidade, mas também para aqueles que alimentam as desigualdades sociais. Por isso, a importância de se refletir sobre a leitura e a escrita como modos de comunicação, como formas de agir na vida, no mundo.

\footnotetext{
${ }^{6}$ Trecho da escrita produzida pela aluna Alice na aula de Língua Portuguesa com os sujeitos do primeiro ano do Ensino Médio/Técnico.
} 
Vale destacar que nas origens dos estudos linguísticos, os modelos da teoria da informação apresentados são essencialmente lineares, ou seja, tratam da transmissão da mensagem de um emissor a um receptor, sem ocupar-se da reciprocidade ou da circularidade característica da comunicação humana, ou seja, da possibilidade que tem o receptor de tornar-se emissor e de "realimentar" a comunicação, ou do alargamento e complexidade da comunicação que pode, por exemplo, dirigir-se a um destinatário, mas visando ao outro. Assim, Fiorin (2003, p.42) afirma: "Neste sistema interacional importam não apenas os efeitos da comunicação sobre o receptor, como também os efeitos que a reação do receptor produz sobre o emissor”.

Nesse sentido, entendemos que, com o advento da tecnologia, sobretudo com a internet, fazse necessária uma reflexão sobre a produção dos textos na sala de aula. Sem a pretensão de criticar, aqui, o trabalho que a escola desenvolve, para exercitar os gêneros discursivos, este artigo nos instiga a (re)pensar de que maneira podemos entender e por em prática a linguagem no mundo contemporâneo.

Retomamos Paulo Freire, para não nos esquecermos de que há uma realidade de exclusão digital no Brasil, portanto não devemos ignorar essa realidade brasileira que ainda se faz presente nesse tempo contemporâneo. Num tempo de novas linguagens, entendemos que é mister aproximar tanto o educador quanto o educando dessas novas ferramentas tecnológicas.

A exclusão, entretanto, não se refere apenas ao não acesso aos aparatos tecnológicos. Ela perpassa as relações sociais e as maneiras como o outro pode se tornar visível ou invisível nessa relação, os modos como ele se torna presente ou ausente nos nossos discursos, na materialidade da linguagem, como diz Bakhtin.

Um grande desafio está lançado a todos os educadores que lidam com jovens e adolescentes no mundo contemporâneo: o desafio do diálogo. Talvez, nos aproximarmos deles seja um grande rumo a ser seguido; ouvi-los e os termos como interlocutores suscite um pacto de companheirismo que nos aproxima deste grande movimento chamado língua.

É nessa atividade linguística que o ser humano encontra a sua própria autonomia, que se mira no direito de pensar, aprender, ensinar, conceber, opinar, sentir, sonhar; uma premissa para que a linguagem seja, portanto, um ato de liberdade.

Nessa perspectiva, esperam-se avanços significativos no processo ensino-aprendizagem, pois o dinamismo e a motivação fazem andar o carrossel dos sentidos nas ações pedagógicas com a língua materna. 
Assim, o ensino de Língua Portuguesa pede passagem para uma discussão nas Ciências Humanas. Quem sabe, um trecho da escrita poética de Capparelli (2015) nos inspire a dar conta desta reflexão: "E se, esquecida a senha, tentares abrir a janela, te vira, meu filho, [...] Te vira para mim, que eu te estenderei a mão.”

\section{REFERÊNCIAS}

ANDRADE, Carlos Drummond de. A palavra mágica. 2. ed. Rio de Janeiro: Ed. Record, 2004.

ASSIS, Machado de. Memórias póstumas de Brás Cubas. 5. ed. São Paulo: Sá editora, 1998.

BAKHTIN, Mikhail. Marxismo e Filosofia da Linguagem. 12. ed. São Paulo: Hucitec, 1992.

BANDEIRA, Manuel. Antologia dos poetas brasileiros. 2. ed. Rio de Janeiro: Nova Fronteira, 1999.

BASÍLIO, Margarida. Formação e classes de palavras no Brasil. 3. ed. São Paulo: Ed. Contexto, 2004.

BECHARA, Evanildo. Moderna gramática portuguesa. 37. ed. Rio de Janeiro: Ed. Lucerna, 2001.

CAPPARELLI, Sérgio. 111 poemas para crianças. 13. ed. Rio de Janeiro: L\&PM, 2015.

CHARLOT, Bernard. Da relação com o saber: elementos para uma teoria. 3 ed. Porto Alegre: Artmed, 2000.

ELIA, Sílvio. Orientações da linguística moderna. 2. ed. Rio de Janeiro: Ao Livro Técnico, 1978.

FIORIN, José Luiz. Introdução à Linguística. 2. ed. São Paulo: Contexto, 2003.

FREIRE, Paulo. Pedagogia do Oprimido. 42. ed. Rio de Janeiro: Paz e Terra, 2005.

FREITAS, Maria Tereza de Assunção. Leitura e escrita de adolescentes na internet e escola. 1. ed. Belo Horizonte: Autêntica, 2005.

FURLANI, Lúcia M. Teixeira. Autoridade do professor: meta ou mito. 5. ed. São Paulo: Ed. Cortez, 2004.

GUIRAUD, Pierre. A estilística. 1. ed. São Paulo: Mestre Jou, 1970.

KATO, M. No mundo da escrita. 2. ed. São Paulo: Ática, 1987.

KRISTEVA, J. História da Linguagem. 4. ed. Lisboa: Edições 70: 1988.

LYONS, John. Linguagem e Linguística: uma introdução. 1. ed. Rio de Janeiro: LTC, 1987.

ORLANDI, Eni Pulcinelli. A linguagem e seu funcionamento: as formas do discurso. 2. ed. Campinas: Pontes, 1987.

VIEIRA, Antônio. Sermões - Padre Antônio Vieira. 25. ed. São Paulo: Ed. Hedra, 1998.

\section{RESUMO}

A vocação deste artigo é a de procurar contribuir para o debate sobre ações pedagógicas diferenciadas junto ao ensino de Língua Portuguesa com os sujeitos do Ensino Médio. Entende-se que é na interação em diferentes instituições sociais que o estudante aprende e apreende as formas de funcionamento da língua, assim como os modos de manifestação da linguagem. Este estudo se debruça na teoria sociointeracionista e na teoria dialógica da linguagem, que trazem à baila a ideia de que a língua se produz nas relações sociais. Nesse sentido, os estudiosos Fiorin (2003), Freitas (2005) e Bakhtin (1992) ajudam a pensar que as relações entre mundo e linguagem nascem das demandas sociais, fazendo andar o carrossel das experiências linguísticas dos estudantes da última etapa da Educação Básica.

Palavras-chave: Ações pedagógicas; Linguagem; Educação. 
CONNECTED ON THE INTERNET, INSPIRED IN SCHOOL: EDUCATIONAL ACTIONS WITH THE PORTUGUESE LANGUAGE IN IFRJ

\section{SUMMARY}

The vocation of this article is to seek to contribute to the debate on educational activities differentiated by the teaching of Portuguese language with the subjects of high school . It is understood that it is the interaction in various social institutions which the student learns and grasps the language of the operating forms, as well as modes of manifestation of language. This study focuses on sociointeractionist theory and dialogical theory of language, which mooted the idea that language is produced in social relations. In this sense, the Fiorin (2003), Freitas (2005) and Bakhtin (1992) help to think that the relationship between world and language born of social demands, making walking the carousel of language experiences of the students of the last stage of basic education.

Keywords: Pedagogical actions; Language; Education. 